\title{
DOSSIÊ
}

\author{
Camila Monteiro Schenkel \\ João Kehl \\ Rafael Jacinto \\ Pio Figueiroa \\ Carolina Lopes
}

\section{Quatro olhares para Cia de Foto}

\section{Resumo}

Ao longo de dez anos de atividade, o coletivo Cia de Foto desenvolveu trabalhos em artes visuais, jornalismo e publicidade. A insistência em creditar suas obras apenas ao grupo, sem indicar qual ou quais integrantes estavam envolvidos diretamente em sua produção, colocou a Cia de Foto no centro das discussões sobre autoria e sobre as formas de produção de fotografia na contemporaneidade. Entre 2003 e o final de 2013, quando anunciou o encerramento de suas atividades, o coletivo foi expandindo e transformando sua atuação, além de passar por diversas formações e tentativas de organização. As entrevistas a seguir apresentam um balanço da trajetória do grupo a partir do ponto de vista dos quatros membros que integravam seu formato final: Carol Lopes, João Kehl, Rafael Jacinto e Pio Figueiroa.

\section{Palavras-chave}

Coletivos. Fotografia. Arte Contemporânea. Autoria.

Como citar:

SCHENKEL, Camila Monteiro; KEHL, João; JACINTO, Rafael; FIGUEIRO, Pio; LOPES, Carolina. Quatro olhares para Cia de Foto. Porto Arte: Revista de Artes Visuais. Porto Alegre: PPGAV-UFRGS, v. 22, n. 37, p.1-28, jul.-dez. 2017. e-ISSN 2179-8001. DOI: http://dx.doi. org/10.22456/2179-8001.76316 


\section{ENTREVISTA COM JOÃO KEHL E RAFAEL JACINTO}

\section{CAMILA SCHENKEL:}

Por que vocês resolveram começar a trabalhar em conjunto com fotografia?

\section{RAFAEL JACINTO:}

Eu conheci o Pio em 2000, quando fazíamos parte da equipe que fundou o jornal Valor Econômico. Trabalhei no Valor de 2000 até o final de 2003, quase quatro anos. Eu já tinha trabalhado em outros jornais e seguia uma carreira de fotojornalista, mas o Valor tinha um perfil bem diferente, era um trabalho mais voltado para retratos. Nos jornais, por mais que fosse uma equipe, não havia um espírito de equipe, de discutir em conjunto projetos maiores, essas coisas. E eu e o Pio nos identificávamos muito por essa vontade de querer estudar. O Pio saiu antes e eu fiquei como coordenador de fotografia do Valor. Eu pautava a equipe e passava muitos trabalhos para ele, porque ele era um bom fotógrafo. Começou a acontecer de pegarmos trabalhos como fotógrafos freelancers e um cobrir o outro por questões de horários, para podermos fazer outras coisas sem deixar de ganhar dinheiro. Às vezes, eu ia fazer um trabalho para ele, às vezes, ele fazia para mim, começou a rolar super bem. Em 2003, teve uma crise bem feia no jornalismo. O Pio já estava fora, freelando, e eu estava cansado do jornal e pedi para me demitirem para fundarmos juntos a Cia. Pelo fato de termos trabalhado no Valor, nos chamavam muito para fazer trabalhos para empresas, fotografar executivos, coisas assim. Quando ligavam para pedir um freela, não falávamos um nome, falávamos que iríamos, mas que não sabíamos se iria eu ou o Pio.

CS:

Nesse caso, seria um formato mais de agência?

\section{RJ:}

Era uma coisa de dupla mesmo, ia quem estava disponível. Montamos essa equipe no final de 2003. No começo de 2004, o João veio trabalhar conosco, ele era assistente de um amigo nosso. A ideia de montar um grupo era para 
poder conseguir viver de fotografia. Quando nos contratavam, já deixávamos claro que o trabalho poderia ser feito por mim ou pelo Pio, e depois pelo João ou pelas outras pessoas que passaram pela Cia. Não tinha essa coisa de pegar um cliente para uma pessoa ou outra, mas resolver um trabalho.

\section{JOÃO KEHL:}

Isso foi bem difícil, as pessoas não aceitavam muito, ligavam diretamente para falar com o Pio ou com o Rafa. Demorou muito para isso ser de fato uma coisa natural. O mercado não entendia, acho que nunca entendeu direito. [...]

\section{CS:}

Essa posição de vocês tinha um caráter de provocação? Era uma bandeira naquele momento?

\section{RJ:}

Lá em 2003,2004, tínhamos muita vontade de poder estudar, desenvolver uma linguagem, alguma coisa, e trabalhar, viver disso sem ter uma agenda tão louca.

CS:

Quando tu falas em desenvolver alguma linguagem, é no sentido de desenvolver um trabalho autoral?

RJ:

É. Eu, particularmente, tinha muita vontade de participar de exposições, de ter um trabalho artístico, de ter uma galeria - o que nós conseguimos depois de várias articulações e muito tempo dedicado. Sozinho eu não conseguiria, porque eu trabalhava muito. Naquele momento, trabalhávamos para o mercado editorial e a quantidade de grana que entrava era muito menor. Depois migramos para o mercado publicitário e começamos a ter mais tempo.

\section{CS:}

Essa opção por trabalhar em conjunto também pode estar relacionada a essa crise do fotojornalismo?

\section{RJ:}

Não. Queríamos ter essa liberdade de pegar trabalhos grandes, bons, e saber que a equipe iria dar conta, independente do que fosse. A reunião foi para poder nos estruturar e criar um ambiente com espaço para a pesquisa, com tempo para desenvolver trabalhos mais autorais, mais artísticos. 
JK:

Mas acho que foi uma coisa meio tentativa e erro, sabe? Você perguntou se havia uma ideia de provocação por trás, não era isso, foi uma coisa meio natural. Experimentamos trabalhar de vários jeitos. Teve época em que havia fotógrafo contratado, treinamos assistente que depois virou fotógrafo... Mas teve uma hora em que começamos a ver que isso não dava certo. Acho que o momento em que isso começou a ficar mais consciente foi quando começamos a precisar nos defender. 0 pessoal veio para cima, tivemos que de fato entender o que era o coletivo e transformar isso em algo mais conceitual. Fomos mudando muito ao longo do tempo, amadurecendo a ideia.

\section{RJ:}

Acho que o Edu Brandão ajudou muito a entender. Eu já conhecia ele da faculdade e da Folha. Ele abriu a Galeria Vermelho um ano antes da Cia.

\section{CS:}

Quando a Cia começou a ser representada pela Vermelho?

RJ:

Oficialmente em 2008. Em 2004, no ano em que João entrou, o esforço ainda era para tentar entender como seria a Cia. Tivemos equipe, contratamos fotógrafo, não deu certo. 0 Júlio Bittencourt entrou no final de 2004. Em 2005, a Cia alugava uma casa na mesma vila que o Fotosite, que era uma agência e um site de fotografia. Eles realmente agitaram, tinham um espaço de exposição, organizavam encontros. Foi um ano bem importante para nós. A entrada e a saída do Júlio geraram muitas brigas entre nós e também fizemos nosso primeiro ensaio, chamado 911 . O Júlio saiu no meio do processo e fez um trabaIho sobre o mesmo tema, na mesma época. É um trabalho sobre uma ocupação do Movimento dos Sem-Teto na Avenida Prestes Maia, número 911. Foi o nosso primeiro trabalho autoral, assinado como Cia de Foto. Era um trabalho multimídia, isso lá em 2005, que combinava fotografia, vídeo e música.

Em 2006, o Fotosite nos indicou para o Festival de Arles com esse trabaIho. Fomos selecionados para a Noite do Ano, que é uma noite de projeções. 0 Edu Brandão foi representando a Galeria Vermelho. Viajamos juntos, eu, ele e o Pio, foi muito legal. Ele pôs muita pilha na nossa cabeça. Para o Edu, e para o mercado da arte, não era um problema trabalhar em coletivo. Ele gostava desse questionamento e nos provocava, ajudava a entender o que queríamos fazer. Ficamos muito próximos, ele foi o curador da nossa primeira exposição individual, no Itaú Cultural, em 2007. Foi nessa época em que começamos a aparecer mais e a precisar nos posicionar. Depois de Arles, nos chamaram para participar 
de muitos festivais. Em 2007, fizemos nossa primeira individual e, em 2008, teve o primeiro Encontro de Coletivos aqui em São Paulo, organizado pelo Claudi Carreras. Ao mesmo tempo, havia uma resistência das pessoas do meio, desses caras mais velhos - a Simonetta Persichetti brigava muito conosco, o Milton Guran... Brigavam de verdade mesmo, iam a palestras nossas e começavam a gritar que o que estávamos fazendo era uma coisa irresponsável.

JK:

Aquela coisa de "a gente lutou muito para assinar o direito de assinar nossas fotografias e agora vocês estão derrubando tudo".

CS:

Mas vocês estavam assinando, não? Observando o trabalho da Cia, me parece que vocês foram criando uma marca. Não era uma questão de ausência de autoria, só não era uma autoria individual.

RJ:

Tinha muita autoria, né? Visualmente era muito identificável. E isso lá na frente acabou virando uma receita para nós que, no final, estava me incomodado.

CS:

Esse formato foi algo planejado ou foi sendo construído durante o desenvolvimento do trabalho?

\section{RJ:}

Foi sendo construído. A Carol entrou em 2007 e a entrada dela ajudou muito a entender. Até então eram três fotógrafos: eu, o Pio e o João. Os três fotografavam, tratavam as fotos, criavam o conceito, sempre com a ajuda de pessoas de fora, como o Edu Brandão, o Claudi Carreras, esse curador espanhol que nos levou para o mundo inteiro, o Eder Chiodetto [...].

JK:

O Claudi estava viajando e começou a perceber que havia esse fenômeno de coletivos, que isso não deveria estar acontecendo à toa. Ele passou dois anos viajando e depois fez uma exposição chamada Laberinto de Miradas. O Claudi nos ajudou a conhecer os coletivos de fotografia porque nós não conhecíamos de fato, né? Mas eram poucos coletivos que tinham um formato parecido com o nosso, nenhum assinava coletivamente. 
CS:

Além de assinar em conjunto, o trabalho de vocês chamou muito a minha atenção por ser realmente feito de forma coletiva.

\section{RJ:}

A entrada da Carol teve muito a ver com isso. [...] Quando a Carol entrou, foi uma forma de dizer que havia uma integrante nova no coletivo que não era fotógrafa, ao menos, no sentido tradicional do termo. Ela entrou para trabalhar na pós-produção, para pegar nossas imagens e ir tratando, editando, relacionando uma com a outra, conosco ou sozinha. Ficava mais fácil de entender que havia uma autoria coletiva com vários estágios antes ou além do clique e que, inclusive, tinha uma pessoa que não clicava, mas que era fotógrafa da Cia.

CS:

E esse trabalho da pós-produção foi ganhando importância?

\section{RJ:}

Completamente. $\mathrm{O}$ que você disse que dava para identificar como Cia de Foto vinha da pós-produção. O Guerra, que foi um trabalho exposto no Encontro de Coletivos e na exposição Geração 00, do Eder, foi todo criado revisitando o nosso acervo e transformando essas imagens em preto e branco de forma a criar um novo significado. A pós-produção era uma coisa muito importante na Cia e a Carol encabeçava isso. Era muito legal, ficávamos aqui, juntos, e às vezes as coisas saíam. Em algumas fases não estávamos muito bem e aproveitávamos algum agente externo, o Eder, o Claudi, o Edu... Tinha momentos em que não conseguíamos resolver internamente, gostamos de falar isso porque a Cia era mais do que só a gente, sabe?

\section{CS:}

Como era o processo de trabalho? As coisas eram muito discutidas?

\section{RJ:}

Muito, era tenso às vezes.

\section{CS:}

Vocês continuaram discutindo durante os dez anos?

\section{RJ:}

Sim. E um dos motivos pelo qual a Cia terminou foi que ninguém mais estava com paciência para discutir. Começaram a acontecer coisas que não estavam agradando todo mundo internamente, vontades diferentes... 
CS:

Tudo o que vocês faziam durante a época da Cia era da Cia?

\section{JK E RJ:}

Era.

CS:

E tem algum trabalho que vocês identifiquem como o mais representativo do modo da Cia de Foto de trabalhar?

RJ:

O Caixa de Sapato foi muito importante porque reunia a produção que era de cada um...

JK:

O 911, por exemplo, foi um ensaio estritamente documental, muito em cima do repertório que tínhamos na época [...] Tinha essa ideia de que o fotógrafo tem que ir a algum lugar para documentar alguma coisa, sair do seu mundo para o seu trabalho ter valor. E aí, em algum momento, começamos a olhar para nós mesmos. Veio um pouco de uma conversa com o Edu, que falou que nós tínhamos que começar a olhar para a nossa própria vida. E era uma coisa que eu fazia desde sempre, eu fotografava muito meus amigos, na época da faculdade, ainda com filme. E começamos, dentro da Cia, a fotografar a nossa própria vida, olhar para dentro, em vez de olhar para fora. O Rafa fotografava o filho dele, eu fotografava a minha namorada e os meus amigos, o Pio fotografava os filhos dele...

\section{RJ:}

Tinha uma coisa meio de Nan Goldin, de quem gostávamos muito, coisas que também provocavam, sabe?

JK:

Um dia olhamos para aquilo e falamos "tá, e como isso vira um trabalho coletivo?". A ideia do objeto caixa de sapato resolveu isso, a caixa de sapato é aquele lugar onde você enfiava as fotos de família e nunca sabia quem tinha feito a foto. Era mais importante o objeto e a relação afetiva que as pessoas tinham com as imagens do que se a foto tinha sido feita pelo tio, pela avó ou pelo sobrinho. Na época, a nossa caixa de sapato acabou sendo o Flickr. Criamos uma conta no Flickr e fomos jogando as coisas lá dentro, sem nos preocupar em dizer quem tinha feito. Foi virando uma bagunça. Quando lançamos o vídeo, muita 
gente achava que morávamos todos juntos, para você ter ideia [risos]. Para mim, foi a prova de que o trabalho tinha funcionado, tinha virado tudo uma coisa só, uma ideia de família.

\section{RJ:}

É difícil tentar explicar uma coisa só porque é tudo muito interligado. Teve muito do Edu Brandão na provocação do Caixa de Sapato. Mostrávamos as coisas para ele e ele dizia "gente, as fotos são lindas, mas não vejo vocês nelas". Isso principalmente com os retratos, que era como ganhávamos dinheiro. Para mim, fotografia documental era uma coisa de extremos, eu já tinha ido para o Ceará fotografar jangadeiros, o Pio tinha ido para o sertão. O Caixa de Sapato foi um jeito de olharmos para nós mesmos e retratarmos a classe média. Era uma discussão bem presente ali, por 2005 e 2006. Não existia um documento da classe média, ninguém fotografava a classe média [...]. E virou um certo exercício, também.

CS:

Também tinha uma questão ficcional.

JK:

É, ficava muito nesse limite. E é muito louco pensar que todos esses grandes fotógrafos documentaristas também fotografavam a própria vida, mas não mostravam. Deve haver preciosidades absurdas!

\section{RJ:}

Acho que foi nosso trabalho mais importante, em todos os aspectos. Olhando hoje, ele é meio careta. 0 vídeo não, mas as fotos sim. 0 vídeo, em 2008, tinha uma estrutura que era um pouco nova, mesclava vídeo com foto, tinha um ritmo... Era quase um curta-metragem.

\section{CS:}

O que tu queres dizer com "careta"?

\section{RJ:}

Só havia fotografias de pessoas, sabe? A forma era careta, Era tudo igual!

JK:

Ah, não era careta não. Talvez o que você está chamando de careta fosse uma mentalidade nossa em relação ao que mostrar. As fotos em si não eram caretas... 
CS:

As fotografias de cotidiano que aparecem mais no campo da arte não costumam ser tão bonitas quanto as da Cia.

RJ:

Quando lançamos o Caixa de Sapato também houve essa discussão por parte do campo da arte.

JK:

Ah, mas tem um papo chato no campo da arte, nada pode ser bonito, sabe? Tem muita gente que pensa que trabalho de artista tem que ser mal-acabado, não pode ser bonito, senão vira outra coisa [...].

\section{RJ:}

As pessoas se incomodavam com nosso domínio da técnica, diziam que nossas fotos pareciam demais com publicidade. Mas não pareciam com publicidade, fazemos publicidade e esses trabalhos não têm nada a ver com isso. Tanto que nunca conseguimos aplicar o Caixa de Sapato na publicidade, de fato.

\section{CS:}

Mas houve trabalhos da Cia que transitaram entre o campo do fotojornalismo, da publicidade e da arte, não?

RJ:

Fotojornalismo sim, publicidade não. Publicidade é muito difícil, você tem um cliente. Em fotojornalismo teve o Políticos, um trabalho feito para a Folha de $S$. Paulo, publicado no jornal, mas que tinha toda uma conceituação artística, tanto que ele foi exposto desse jeito, na própria folha de jornal. Para mim, é um dos trabalhos mais legais que temos. Tinha também uma pesquisa nossa da época, que também está no Caixa de Sapato, que é a questão dos horários, a sincronia no momento das fotos. As câmeras digitais têm metadados que registram o horário das fotos. Nós deixávamos as câmeras todas com os mesmos horários. Quando nos chamaram para fazer a campanha, falamos que tínhamos essa ideia de sincronizar as três câmeras e fotografar cada um dos candidatos em um dia de campanha - selecionar um momento em que as três câmeras estão sincronizadas - para mostrar o efeito da campanha política, como o fotógrafo determina o que é mostrado quando enquadra, que não há imparcialidade. [...]

CS:

Vocês também tinham muitos trabalhos que ficam entre a fotografia e o vídeo. 0 Longa Exposição, por exemplo... 


\section{RJ:}

Nesse aspecto, acho que contaminei um pouco a Cia. Eu curtia fazer vídeos, mas não era algo muito comum na época. Para o 911, tivemos que chamar um amigo que tinha uma câmera de vídeo. Os vídeos do Caixa de Sapato foram feitos com uma Canon pequenininha, ainda não existiam as câmeras que faziam as duas coisas. Aí, quando lançaram a Mark II, começamos a fazer retratos filmados, mas ninguém sabia ainda que as câmeras podiam fazer vídeos. Voltamos a trabalhar para revistas só para fazer esse trabalho. Nós ligávamos para as revistas e dizíamos que estávamos a fim de fazer retratos de gente legal, mesmo ganhando pouco. Então nós íamos, fazíamos a pauta e, no final, pedíamos para fazer mais uma foto em um fundo branco. Colocávamos a câmera em um tripé e ficávamos até o limite. Conceitualmente é um trabalho muito legal, mas hoje em dia ninguém mais cai. [...]

JK:

Sempre teve um lado meio nerd, de experimentar com tecnologia, entender como a câmera funcionava.

\section{RJ:}

Experimentávamos muito e naturalmente a tecnologia era uma coisa que nos atraía. Quando fizemos o Caixa de Sapato, fomos convidados pelo Heitor Dhalia para dirigir filmes de publicidade. Ele abriu uma produtora de filmes publicitários, a Paranoid, e a mulher dele era amiga da mulher do João, na época. A coisa começou pelo trabalho artístico e, na hora de aplicar, passou para o campo da publicidade. Aproveitávamos as coisas dos dois lados. [...]

\section{CS:}

E a questão da apropriação de imagens? Como apareceu no trabalho da Cia?

\section{RJ:}

Dialogava muito com o trabalho da Rosângela Rennó. Era uma artista que admirávamos muito e, por causa da Vermelho, acabamos ficando próximos. 0 trabaIho dela é completamente em cima de apropriações. No nosso caso, era mais um trabalho de apropriação do nosso próprio acervo. O Guerra é isso. 0 trabalho do Glauber, que acabou se chamado País Interior, veio em um momento em que estávamos com uma pesquisa em cinema e queríamos fazer um trabalho sem fotografar, mas que não fosse do nosso acervo.

CS:

Foi o primeiro trabalho com imagens que não eram de vocês? 


\section{RJ:}

Foi. Tem um trabalho de colagem do John Stezaker no qual ele pega dois negativos de filme e cria um novo. Eu trouxe um livro dele para cá e disse "olhem isso, temos que fazer um trabalho com isso". A forma é completamente diferente, mas era algo que nos interessou muito. O Pio se entusiasmou, a Carol viu e decidimos extrair os frames do Glauber. Então pensamos no processo da Cia, que era a pós-produção, e virou um trabalho de colorir um filme em preto e branco. A Giselle Beiguelman estava fazendo uma exposição baseada no Glauber Rocha no Instituto Tomie Ohtake. Ela ficou sabendo do trabalho e quis expor. Só que teve uma parte de texto que ficou mal definida, tem uma pesquisa de som do Guab que também ficou muito mal exposta. O Guab pegava os diálogos do filme e transformava cada sílaba em um tom, criando uma música a partir dos fonemas, a partir de uma regra que ele criou [...]. Foi um trabalho exposto ainda em processo, acho que ficou mal resolvido. Mas tudo bem porque, quando foi exposto, havia esse caráter experimental.

JK:

Tinha uma certa ansiedade na Cia, não?

RJ:

De não esperar os trabalhos acabarem... E essa ansiedade não era nossa.

JK:

O Pio é um cara muito ansioso. Muitas vezes ainda estávamos no meio do processo e ele já queria colocar na rua. Acho que esse trabalho merecia amadurecer um pouco, mas acabou saindo meio no empurro. Trabalhar em coletivo não é fácil. É legal para caramba, tanto que conseguimos aguentar por dez anos, mas em muitos momentos...

CS:

Qual era o papel das individualidades dentro do grupo? Muita gente fala de um apagamento das individualidades dentro de um coletivo.

JK:

O coletivo só funciona quando as individualidades são muito fortes, porque cada um acrescenta coisas diferentes. [...] Acho que existem dois momentos, o do coletivo saudável, quando as forças individuais se somam, e o do coletivo que começa a falhar, que é justamente quando as individualidades começam a morrer e o coletivo começa a ficar capenga. 
CS:

Vocês tinham papéis definidos, havia alguém que trabalhava mais com determinadas coisas?

RJ:

Sim, mas isso foi bem no final, já tentando solucionar essa crise de indivíduos que havia aqui dentro. Eu cuidava da Paranoid, os filmes publicitários eram comigo. O Pio cuidava dos workshops, que eram uma vontade dele [...]. A Carol cuidava muito da galeria e das exposições e o João principalmente dos trabaIhos de fotografia, especialmente para matérias, revistas. E tinha a Flávia, que está conosco até hoje, que coordenava toda a Cia. Foi ela quem deu o alerta vermelho, nos chamou e avisou que o dinheiro tinha acabado. E aí a Cia decidiu terminar. Não foi só por causa da grana, mas quando a grana falta os problemas aparecem. Existiam essas funções, mas mudou muito ao longo dos anos.

\section{CS:}

No início era mais nos moldes de todos fazem tudo?

\section{RJ:}

Isso. Mas no começo as coisas eram mais simples, atuávamos só no mercado editorial e tínhamos a pretensão de ser artistas. Como começamos a viajar para festivais, workshops, a ter que lidar com galeria, produtora de filmes, clientes de foto, agências, não teve como evitar essa divisão.

CS:

E os trabalhos de arte, atualmente, como estão?

\section{RJ:}

Eu e o João ficamos muito cansados do mundo da fotografia, foi muito exaustivo. Quando terminou, eu, o João e a Carol falamos "chega, eu não quero mais saber disso".

JK:

São sempre as mesmas pessoas, as mesmas conversas, é um meio que se repete muito, precisávamos de férias [risos].

RJ:

Tudo que está impresso nessa parede são projetos. Estamos voltando aos poucos, com calma, sem vontade de ter galeria, nos inscrevendo em editais. Ano que vem, vamos começar uma parceria com uma produtora cultural para tentar fazer livros, que é um suporte que gostamos muito. 


\section{ENTREVISTA COM PIO FIGUEIROA}

\section{CAMILA SCHENKEL:}

Pio, tu poderias começar falando um pouco sobre a tua história com a fotografia e sobre o início da Cia de Foto?

\section{PIO FIGUEIROA:}

Eu comecei no fotojornalismo. Não fui para a faculdade, eu tinha um acordo com o meu pai, que me disse para esquecer a história de faculdade naquele momento que ele me daria uma grana mensal para montar uma estrutura de foto. Eu tinha equipamento, laboratório preto e branco, comprava livro de fotografia, ia para festivais, conhecia o pessoal... Menos de dois anos depois, já estava dentro do jornal. Com vinte anos de idade, tinha carteira assinada e salário sênior. Um ano depois, a dinâmica de um jornal já parecia pouco e decidi vir para São Paulo. Quando esgotou, e esgotou cedo, eu tinha um pouco menos de dez anos de mercado e não tinha muito para onde ir com o jornalismo. Isso ocorreu em um período com dois aspectos interessantes, uma era o do boom da internet, com salários altos e três convites por ano para trabalhar em coisas, e o outro era o da tecnologia digital, com muita gente indo embora, o mercado quebrando. No meio dessa história, no jornal Valor Econômico, tive a experiência de fazer, pela primeira vez na vida, um jornal que não ia para a rua. Nos seis meses antes dele começar a rodar, me dei conta de uma questão fundamental - eu estava experimentando uma fotografia cujo uso não era objetivamente justificável. Eu não ia fotografar você aqui para aplicar em alguma coisa amanhã. Era uma espécie de branding, um laboratório interno, para descobrir a linguagem do jornal [...]. Quando começou a ir para a rua, foi um balde de água fria. Eu consegui uma licença, passei um ano fora e, quando voltei, já voltei em um processo de pedir demissão e com a ideia de que tínhamos que fazer um coletivo de fotografia. Eu tentei com o Kiko Ferrite e com a Renata Ursaia. Os dois não acreditaram nessa ideia de coletivo, quem acreditou foi justamente o Rafa.

\section{CS:}

Que também trabalhava no Valor?

PF:

Isso. Nós tínhamos um pouco mais tempo de mercado, ele vinha em seguida. Quando eu estava saindo do estúdio do Kiko, já com essa ideia de fazer um coletivo, ele demitiu o João, que era assistente dele [...]. Só que, quando o João foi embora, ele deixou um envelope com fotos na minha mesa. Quando vi as 
fotos, eu me apaixonei, fiquei tentando trazer ele para a estrutura que estávamos montando. Na primeira vez, não deu, na segunda, não deu, mas uma hora deu. E quando ele veio, veio também uma dinâmica de não fazer nada separado. Até que uma hora eu comecei a olhar para o resultado e perceber que não dava mais para considerar como se fosse de uma pessoa só, como sendo do Pio. Acho que eu, fotograficamente, cresci muito com a Cia de Foto. Foi ganhando uma dinâmica por sermos três pessoas ávidas, processando informação, com um poder de autocrítica brutal, sem muita preocupação com o lado financeiro. Se eu fizesse três retratos por mês, eu tenha um salário interessante para alguém de 20 e pouco anos na cidade de São Paulo. 0 resto era tempo livre que podíamos transformar em pesquisa. E aí começou essa história de qualificar o nosso tempo. No momento em que começamos a não querer assinar mais individualmente, veio uma figura muito curiosa no mercado, que é a Simonetta Persichetti...

\section{CS:}

Mas em que momento foi isso?

PF:

A época no Valor Econômico foi de 1999 para 2000. Em 2001, eu fiquei fora, em 2002, voltei para o Valor e depois pedi demissão. Entre 2000 e 2003, fiquei tentando criar o coletivo e, em 2003, criou-se a Cia. Em 2004, o João entrou.

\section{CS:}

Vocês já assinavam coletivamente em 2003?

\section{PF:}

Não, para ter segurança, eu diria que foi em 2005, porque o João já estava conosco. Em 2004, ainda rolava certa separação de agendas, principalmente por choque cultural. O Rafael era meio paulistão, tinha uma coisa de "isso aqui é meu, isso aqui é seu". Eu era mais anárquico. Para mim, teve o seguinte marco: o Pisco del Gaiso estava fazendo a Semana de Fotografia da FNAC, viu o 911 e nos chamou para dar uma palestra. Foi a primeira vez que eu dei uma palestra sobre o meu trabalho [...]. Saí dessa palestra pensando mais sobre minha produção, me vendo de fora, pensando nas porradas que levei já nessa primeira exposição. Acho que a semente foi plantada ali. Em 2005, começou a correr um bochicho silencioso: começamos a ter trabalhos recusados, as pessoas pararam de ligar. Ou começaram a ligar exigindo saber quem ia fotografar. Começamos a sentir que tinha esse estranhamento. Aí veio esse texto da Simonetta no Estadão, seria até interessante analisar o conteúdo real dele hoje. Na época, 
foi muito forte porque veio gratuitamente. Ela nunca tinha conversado com nenhum de nós, tínhamos uma simpatia por ela e ela estava ali falando que o que estávamos fazendo era absurdo.

\section{CS:}

O absurdo era trabalhar coletivamente com fotografia?

\section{PF:}

Isso. E acho que ela criticava o resultado da foto também. Mas já estávamos colhendo algumas coisas, sabe? Já tínhamos conseguido fazer com que o João ganhasse o World Press Photo, que foi um negócio arquitetado pelo grupo, lindo. Como o mercado estava resistindo ao nome do João, sentimos que precisávamos encontrar uma maneira de fazer esse cara se projetar. Ele passou no curso Abril, passou no trainee da Folha e ganhou o World Press com um ensaio de uma academia de boxe em baixo de uma ponte. [...] No dia em que saiu o resultado, eu estava em Olinda. Eu olhei, liguei para todo mundo e estávamos ainda comemorando quando já veio o mercado tentando estragar a festa, dizendo que o vencedor tinha sido um só, que essa coisa de coletivo no fundo não existe. [...]

Quando veio o prêmio, veio também uma rebordosa, esse fluxo absurdo de implicância conosco. Havia algumas pessoas que detinham os meios. Isso é assim até hoje. 0 único jornal que escrevia sobre fotografia era o Estadão, então, para ser reconhecido, era interessante que seu trabalho fosse bem visto pela Simonetta. Mas, na hora em que ela levantou essa história e o mercado caiu em cima, eu tive certeza de que não dava para voltar atrás. Já que não tinha mais grana do jornalismo, então era hora de correr atrás de outro tipo de grana. Em 2006, acabou o dinheiro. Foi muito sério, o mercado boicotou. [...] Então partimos fomos procurar outros espaços para fotografar e decidimos não recusar os convites de festivais. 0 primeiro foi o de Arles, de cara, um dos principais. Fomos para o sul da França com o 911, um trabalho que, quando viajei, já estava vendo de maneira mais crítica.

O 911 começou com essa ideia de fotografar uma favela. Até aí, tudo bem. Só que primeiro ele foi capitulado. Depois eu chamei um amigo, o Alex [Carvalho], um cara baseado em Londres que acho que foi quem acabou nos levando para esse lado do vídeo. Falei para ele que queria fazer dessa peça um filme e que a ideia era fazer algo tipo um slideshow, mas que, de repente, uma mulher colocando a roupa no varal se mexesse, uma pessoa saísse andando. Em 2006, antes dessa ideia de câmera 5D de misturar vídeo e fotografia no mesmo aparato, isso causou um impacto. As pessoas queriam saber quem a gente era. Hoje em dia, acho o vídeo careta, mas sei que foi importante. Essa troca com o Alex também foi muito importante. Então, nesse início, enquanto 
o mercado todo estava dizendo que nós não podíamos ser um coletivo, internamente, o coletivo já não se bastava. 0 meu papel lá dentro era de importar pessoas. Isso não parou nunca. Começou com o Pisco e o Alex para chegar ao Ronaldo [Entler] e à Lívia [Aquino]. Ronaldo durante muito tempo foi um cara plugado na Cia. O Guab foi um cara central para o Carnaval, ele quebrou os códigos da fotografia e jogou em uma interface para transformá-los em música, veio para fazer essa pesquisa.

Tinha também o Edu Brandão, que dizia para não ligarmos para essa discussão, que tínhamos que nos livrar das amarras que nos condicionavam a esses dogmas da fotografia. Quebrar o preciosismo, subverter o suporte, subverter a ansiedade de ver uma foto sua grande na parede, isso veio muito do Edu. A nossa primeira exposição no Brasil foi no Itaú Cultural, em 2006, com o Edu editando, e nela não havia uma foto fixa. Era uma porrada de monitores passando fotos, um grande banco de imagens. Ele pegou todo o banco de imagens da Cia de Foto, levou para o Itaú e jogou lá dentro.

Quando a Simonetta começou a bater na gente, as pessoas que nós enxergávamos como parceiros começaram a nos dar mais suporte [...]. Teve episódios horrorosos, palestras acabadas, mil histórias. [...]. Mas isso acabou me dando força, fomos ganhando voz e fomos tomando gosto por esse jogo. Aí, em 2006, o MASP Pirelli, que até então era uma coleção almejadíssima, nos chamou para entrarmos na coleção. E, quando fomos mandar o trabalho, veio a pergunta de quem era a foto. Respondemos que era da Cia de Foto, mas eles insistiram que tínhamos que dizer quem fez. Mandamos os três nomes, mas eles não aceitaram. Tínhamos que dizer exatamente de quem era a foto ou não entrávamos na coleção.

\section{CS:}

E qual era a fotografia?

\section{PF:}

Eram três fotos do 911. Na época, o coletivo discutiu se segurava aquela história ou não. Eu era da parte que dizia que isso seria um retrocesso, que era melhor não estar na coleção. Acabamos abrindo mão e eles colocaram no lugar o trabaIho de um menino que tinha sido nosso estagiário. Aí, em um festival lá em Porto Alegre, que homenageava a Claudia Andujar, o Rubens Fernandes Júnior, que era da coleção, resolveu abrir essa história ao público. Estava todo mundo na palestra e ele falou sobre o trabalho da Cia de Foto e do que tinha acontecido naquele ano. Aí a comunidade fez "blum". A discussão começou a ficar gostosa, isso foi engrossando o caldo, fomos tendo reconhecimento, fomos convidados para exposições fora, ganhamos espaço para textos, passamos em editais... [...] 
CS:

E como o trabalho da Cia foi se transformando ao longo do tempo? Tu falaste um pouco do 911, que tu achas que ainda está mais na área do fotojornalismo, e a Cia começou depois a atuar entre campos, entre o jornalismo, a publicidade, a arte.

PF:

Em relação a romper com a escola do fotojornalismo, a solução foi começarmos a nos fotografar. Não era uma questão muito de dizer, mas simplesmente acontecia. Eu era casado com a Ju, então fotografava ela, João era um menino de faculdade, então fotografava as histórias da faculdade. Com o tempo, o Rafa foi fotografando a vida dele também. Tinha uma coisa de chegar na Cia e descarregar um cartão, sem querer aplicar aquilo que estávamos fazendo, isso foi rolando. [...] Aí um dia de noite eu estava em casa, indo dormir furioso por conta de uma palestra interrompida e, conversando com a Ju, veio a ideia do Caixa de Sapato.

CS:

Nesse momento, a Carol já estava participando?

PF:

Não, ainda não tinha a Carol. Veio uma ideia, nessa noite, do veículo que é a caixa de sapato. Aí eu cheguei na Cia no outro dia e lembrei que uma caixa de sapato é um veículo popular da fotografia, inclusive, universal, e não interessa quem fez a fotografia em uma caixa de sapato. Se você chega na casa da sua avó e olha a caixa de sapato de fotos dela, você não vai dizer que o tio Roberto é um fotógrafo incrível. O que importa são as histórias que elas estão contando. $\mathrm{E}$ a partir do momento em que você quebra a atenção dada à autoria, você começa a jogar com outras ativações. Por exemplo, olhar aquela foto do tio Roberto de calção vermelho com sete anos de idade, quando você tem oito, e olhar essa fotografia agora, são coisas diferentes. É incrível como essa foto caminha, como lá dentro ela vai se elaborando, e, quando você abre essa caixa de novo, ela te conta novas histórias. Ela não só recupera aquilo que contou a vida toda, mas vai atualizando isso, a partir de quem vê. Então estava resolvido, todas as fotos que fizéssemos do umbigo iríamos jogar dentro de uma caixa de sapato. [...] A caixa de sapato começou a ser uma espécie de bauzinho que ia fomentando o trabalho da Cia, sabe? Ela começou a virar uma espécie de acervo estratégico. 0 Guerra saiu do Caixa de Sapato... [...]

Em 2006, percebemos que no jornalismo não tinha mais jeito e, com um trabalho para o Banco Real, nos demos conta de que a publicidade estava 
apontando uma coisa para a gente. Os caras queriam pagar por um tipo de fotografia que sabíamos fazer. Depois do Banco Real, nos contrataram para fazer a Suzano, um monte de coisas. No meio disso, veio a ideia de que precisávamos de alguém só para se dedicar ao Photoshop. Naquele momento, a linguagem que estávamos desenvolvendo estava evoluindo artisticamente, tinha sopros de que aquilo estava funcionando e o comercial estava nos dizendo que teríamos um dinheirinho. Para chamar essa pessoa para fazer o Photoshop, foi uma briga interna. Primeiro veio uma menina chamada Flávia, mas ela não se sustentou e indicou a Carol. Um ano e meio depois, a Carol estava fazendo um Photoshop muito próximo do que esperávamos e dois anos, três anos depois ela já estava melhor do que nós. E a Carol veio com uma coisa de não querer ser fotógrafa, de querer trabalhar na pós-produção mesmo. Aí veio essa ideia de você ter a quarta face do coletivo, que também gerou uma briga interna. Eu achava que não dava para ter funcionário, não queria ser chefe, queria que essas pessoas também fossem donas. E queria criar uma entropia ali dentro para que elas se tornassem donas o mais rápido possível. Óbvio que não tive competência para fazer isso, tanto que dei com os burros n'água. Teria sido melhor ser dono, em tese. Ou não... Enfim, tem um tempo aí que é completamente diferente.

Em outubro de 2006, nos mudamos para Pinheiros e a Carol entrou em seguida. A partir de 2009, isso virou uma produção brutal, porque fotografávamos muito e começava a existir um mercado para a Cia, um mercado híbrido, com pouco jornalismo, mas muito institucional e muita publicidade. Quando o vídeo do Caixa de Sapato saiu, em 2008, a Paranoid, uma produtora que estava surgindo no mercado, nos chamou para sermos diretores de cena. Aí isso começou a ficar muito complexo, tínhamos as raízes no fotojornalismo, o motor conceitual muito ligado à arte contemporânea, uma pretensão de estarmos envolvidos nesse meio, a grana vindo da publicidade e um convite para virarmos diretores de filmes publicitários.

CS:

Muito trabalho para fazer, né?

PF:

É, a atuação era bem maluca, houve uma mudança de chave nesses percursos... $\mathrm{O}$ que aconteceu comigo foi que fui saindo do mercado comercial e carregando na questão conceitual. Fui me envolvendo mais no estudo, lendo...

CS:

Tinha papeis que se cumpriam ali dentro? Como o trabalho se dividia, como era a dinâmica? 
PF:

Tinha. O João ficava muito na parte comercial, ele era o cara que ia sempre para a rua, ia o João e mais alguém. Eu fui saindo disso, e a Carol ficava no Photoshop. Fomos criando uma dinâmica de olhar para o acervo da Cia - isso começou com o Guerra. Em 2010, isso virou uma potência, a Cia levantava um ensaio em três meses, um ensaio dialogava com o outro, uma continuidade de produção absurda. Aí acho que em 2011, 2012 começamos a ter muitas exposições, uma atrás da outra, concomitantes até.

Em 2012, eu entrei na USP. Lá eu conheci os meninos do Movimento Passe Livre, eles eram meus colegas [...]. Quando eles foram fazer aquela passeata, nós estávamos lá juntos. Quando estourou, eu estava vendo os caras levando porrada. Um deles, o Leo, um menino genial, viu um trabalho que expusemos no MASP chamado Marcha, que tinha uma estratégia de exportar os frames de um vídeo, transformar eles de novo em fotografia e destacar um rosto na multidão. 0 Leo dizia que, de alguma forma, quando fazíamos isso, era como se a cidade estivesse iluminando essas pessoas. Eu achava a leitura linda, mas para mim aquilo ainda não segurava. Quando veio a marcha, nós fomos para a movimentação. A primeira foto desse trabalho é da Ju, a minha mulher, na passeata. Depois da primeira noite, eu sentei com a Carol, nós transformamos em preto e branco e eu dizia, "Carol, ilumina uma pessoa". A cidade iluminando uma pessoa. Aí saiu o ensaio. O Thyago Nogueira viu, veio conversar e convidou para publicar na ZUM. Eu falei: se você publicar isso como pôster não precisa mais nada, já vira um trabalho. E então isso virou um pôster na ZUM com um texto do Eugênio Bucci. Logo depois daquilo, fomos convidados para um festival no Chile. Eu e a Carol fomos para a internet, pegamos todas as fotos do movimento estudantil do Chile de 2010 e demos o mesmo tratamento, levamos os nossos estudantes e os estudantes chilenos com o mesmo tratamento. A Carol arrasou, fez um tratamento que, para mim, é a coisa mais linda do mundo. E o fato das fotos serem tiradas do Google... Quando eu estava no Chile, fazendo essa exposição, soube do fim da Cia. $\mathrm{Na}$ verdade, eles começaram a se reunir uma semana antes e me comunicaram no dia 5 de novembro em um e-mail: 5 de novembro de 2013. [...]

Hoje eu penso que a ideia de que todo trabalho comercial da Cia era para sustentar uma coisa com relevância conceitual era uma miragem, uma ideia minha, romântica [...]. Uma coisa gostosa foi descobrir, quando acabou o coletivo, que existia um Pio. Com toda a sinceridade do mundo, eu sabia que eu tinha uma voz, sabia que as pessoas olhavam para a Cia de Foto e meu sotaque se sobressaltava, eu era a pessoa que escrevia os textos, que no fundo tinha uma orientação de futuro, era o provocador ali dentro. Existia uma certa opacidade na Cia. Você percebia o resultado, mas você individualizava também. Para mim, que estava muito envolvido lá dentro, eu não percebia isso. 


\section{ENTREVISTA COM CAROL LOPES}

\section{CAMILA SCHENKEL:}

Podemos começar conversando sobre o teu início na Cia de Foto? Como isso aconteceu?

\section{CAROL LOPES:}

Eu entrei na Cia quando o coletivo já estava formado, entre o final de 2006 e o início de 2007, foi quando o grupo já estava precisando de alguém para aliviar um pouco o tempo deles. Eles estavam trabalhando pra caramba, gastavam muito tempo no computador processando imagens e estavam querendo tentar produzir tempo livre. Não tempo livre no sentido no sentido de não fazer nada, queriam um tempo livre para pensar um pouco sobre a fotografia. Para conseguir fazer isso, eles perceberam que precisavam incorporar uma quarta pessoa no grupo que tivesse um perfil diferente. Eles fotografavam o dia inteiro e passavam a madrugada tratando fotos para poder entregar para o cliente, já que no outro dia já tinham que ir para outro trabalho. Era uma coisa muito corrida. Aí um professor me indicou para os meninos e fui conversar com eles. Eu também estudava com uma menina que, na época, era estagiária deles. Antes disso, eu trabalhava no acervo da Nair Benedicto, digitalizando cromos e fazendo outras coisas. Eu nunca quis ser fotógrafa, sempre gostei de trabalhar em acervo, ou mesmo com Photoshop, mas com as devidas proporções. Antes de entrar no coletivo, não tinha a visão que tenho hoje da ferramenta. Eu fiz uma entrevista, deu certo, e acabei entrando para o grupo. Mas entrei como uma pessoa em formação, eles não me contrataram como uma profissional pronta, para quem é só passar tudo que ela toca sozinha. Uma coisa legal da Cia é que sempre havia esse pensamento de que as pessoas estão em formação, apostávamos muito na construção com o tempo e com a convivência.

\section{CS:}

Qual era a tua visão desse processo, essa ideia de fazer fotografia em conjunto?

\section{CL:}

Para mim, nunca foi um grande problema. Eu sou de Recife e fiz faculdade na Federal de Campina Grande. O nome do curso era algo parecido com Multimeios, se chamava Arte e Mídia. A minha formação já era bastante holística, não havia essa história de autoria única. Até hoje não ligo muito para isso, continuo tratando fotos para outros fotógrafos e não me importo se vão colocar os créditos ou não. Mas isso é uma coisa muito pessoal, não é uma bandeira. Eu só não entendia por 
que era um problema. Ao mesmo tempo, trabalhei com a Nair. Eu sei a luta que foi necessária para que o fotógrafo conseguisse receber os créditos por suas fotografias. Mas, em nenhum momento negamos o crédito, pelo contrário, era uma luta em favor dele. Era uma luta pelo crédito de todo mundo que trabalhou no projeto. É algo meio dúbio, foi bem problemático. Mas foi preciso uns dois anos, que foi o período de formação, até chegar ao ponto em que eu me enxergava colaborando diretamente com o grupo. É difícil essa coisa de datas, mas deve ter sido 2009, 2010, por aí. No final, tínhamos uma sinergia muito boa, algo que não se encontra facilmente. Você falou com todo mundo, acho que o discurso deve ser meio afinado - tirando a história do término, que cada um deve ter falado a partir da sua visão.

0 processo de trabalho era algo muito impressionante. Se você falasse comigo agora e dali a dois minutos, falasse com o Rafa sobre o mesmo trabaIho, o discurso tinha uma continuidade porque tudo, absolutamente tudo, era discutido internamente. Alguém lia um texto e mostrava para o grupo, trazendo uma questão. Alguém estava saindo de férias e o outro o provocava a fotografar alguma coisa. Íamos trocando essa bola e as coisas iam nascendo. Mas, quando perguntam o que eu fazia, a minha posição era basicamente processar arquivos e cuidar do acervo, era bem mais para esse lado. Embora eu encabeçasse a área de pós-produção, os meninos também eram muito bons em Photoshop, especialmente o João, foi uma opção passar para alguém. Como eu fazia isso o dia inteiro, fui criando outros caminhos, mas os meninos entendiam bem, então podiam opinar bastante. Eu trazia uma opção de tratamento e nós discutíamos, batíamos uma bola e eu voltava a trabalhar. Muitas vezes, eles chegavam com uma estética melhor, me passavam, e eu dava uma uniformizada em tudo.

CS:

Quanto tempo o processo de pós-produção costumava levar?

CL:

Ah, na verdade, é infinito, nós terminávamos porque precisávamos levar para a exposição. Em muitos ensaios, fizemos tratamentos diferentes depois. É uma visão minha e que o grupo também tinha: eu não considero que um trabalho é acabado, finalizado, acho que estamos em eterno processo. Quando você assume esse lado processual, é difícil falar "pronto, finalizei". Você quer voltar para aquilo de novo. Retomamos e mexemos em vários trabalhos nossos. Não era uma imagem terminada, ela estava ali e podia ser usada para outra história.

\section{CS:}

E sobre esse momento em que tu começaste a colaborar mais efetivamente com o grupo, tem algum trabalho que tu associes a essa mudança de posição? 
CL:

Ah, é difícil pensar em uma colaboração pessoal... Mas tem um trabalho que acho importante para o grupo que é o Carnaval. Foi quando efetivamente radicalizamos a pesquisa do escuro, de valorização da luz. Tiramos elementos das imagens, não por meio de truques, mas diminuindo a luz delas, valorizando outros elementos. O Carnaval entrou em um viés de pós-produção que mudou um pouco nossa forma de trabalhar, mas não por mérito meu, não cheguei a isso sozinha. Lembro que o João fez o tratamento de algumas imagens, deixando elas bem mais escuras com alguns elementos mais claros, levou para o grupo, e demos uma pirada. Começamos a trabalhar em cima disso. O Photoshop foi sempre uma experimentação dentro da Cia, mas acho que foi com Carnaval que começou a se tornar mais consciente, quando saímos um pouco da experimentação para pensar o porquê de estar fazendo aquilo. Os projetos anteriores tinham uma pesquisa estética, exploravam as possibilidades da ferramenta testando saturação, cor, densidade etc. O Carnaval passou a ter um ponto proposital e, um pouquinho antes disso, o Guerra. São imagens de acervo que juntamos para montar um ensaio como se estivéssemos vivendo uma guerra em São Paulo, trabalhadas a partir de uma pesquisa sobre o tipo de tratamento que as fotos de guerra normalmente têm preto e branco, granulado. Montamos essa ficção a partir do tipo de pós-produção que foi dado às imagens. Foi o momento em que a pós-produção começou a ser pensada. Acho que em qualquer processo é assim, há uma fase de experimentação e, depois dessa fase, é possível criar uma consciência em cima disso.

\section{CS:}

A Cia tinha um diálogo bem forte com o campo do fotojornalismo, principalmente no início, imagino que fosse pela formação dos integrantes.

\section{CL:}

É, a formação do Rafa e do Pio foi na escola de fotojornalismo. A minha e a do João não, o João não viveu essa coisa de campo. Ele também se formou na Cia, começou como estagiário. Houve duas levas aí, o Rafa e o Pio, que vieram do mercado, e eu e o João, que nos formamos dentro do espaço. Por virem do mercado, os meninos tinham vícios, faziam coisas que o mercado às vezes exige, caíam em algumas fórmulas. O João quebrou um pouco isso porque estava vindo da faculdade com aquela coisa da experimentação. São misturas que colaboraram dentro do processo.

\section{CS:}

E o trabalho de publicidade foi ganhando mais espaço com o tempo? 
CL:

Foi. Em quantas pessoas nós éramos? Seis, sete? Uma estrutura dessas é cara. Viver como artista ou como fotógrafo de jornal não paga o suficiente para ter alguém como eu, só tratando das fotos. Nós éramos um grupo, mas recebíamos como se fôssemos apenas um, não recebíamos como se fôssemos quatro. Era um cachê, que já era baixo, rateado em quatro. Não era exatamente essa conta, mas a ideia é essa. A publicidade entrou como uma forma de conseguir viabilizar projetos. $\mathrm{Na}$ época, contratamos uma pessoa de coordenação para nos representar no mercado de publicidade, a Flávia. E foi uma construção, não conseguimos trabalhos do dia para a noite. Em 2010, já estávamos trabalhando muito com publicidade. Foi uma escolha para viabilizar o projeto na época, não acho que fosse o sonho de ninguém trabalhar com publicidade. Os meninos estão com uma pegada maior de publicidade agora, eu não gosto, não trabalho com publicidade de jeito nenhum [risos].

\section{CS:}

E a atuação no campo da arte sempre foi um desejo da Cia? Qual era a tua relação com esse universo?

CL:

É, a minha relação com essa área era um pouco maior. No ápice da Cia, nós tínhamos um espaço, trabalhávamos com publicidade e tínhamos uma produção para o mercado de arte. Funcionava relativamente bem, uma coisa bancando a outra. 0 mercado de arte nos alimentava criativamente para dar soluções inteligentes para a publicidade. Não acreditávamos em uma divisão, uma coisa influenciava a outra. Mas não éramos bem recebidos no meio da arte por fazermos publicidade, as pessoas não entendiam muito. E os publicitários às vezes achavam que, por estarmos sempre em galerias, nós éramos artistas e tínhamos muito dinheiro. Mas a gente não tinha, definitivamente [risos]. Eu sempre conversava com o pessoal da galeria, eu que mandava os arquivos, essas coisas. Então acabamos estreitando um pouco mais a relação. Mas eu não sou muito deslumbrada, para mim tanto faz estar na arte ou na publicidade. Não gosto de trabalhar com publicidade porque meu métier, na publicidade, não é visto de uma forma com a qual eu goste de trabalhar. São efeitos de Photoshop muito pesados, recortes etc.. Tendo opção, prefiro não fazer.

CS:

Houve trabalhos que transitaram entre o fotojornalismo e a arte? 
CL:

Sim, como tínhamos muitos trabalhos encomendados, sempre aproveitávamos o acesso a algo que normalmente não teríamos para tentar produzir uma história para a Cia. O Políticos não foi bem isso, nós que pedimos. A Carla Romero, que era editora de fotografia da Folha, queria que nós produzíssemos uma história para o caderno DNA, que era o caderno das eleições. Nós dissemos que queríamos cobrir um dia ordinário de eleição, mas que queríamos os três fotógrafos em campo. Aí aconteceu o trabalho, cada dia era um candidato e eram os três fotografando. Já o Carnaval foi diferente. A Ivete Sangalo - não sei como ela chegou na gente - nos contratou para cobrir o carnaval dela: o backstage, o palco, todos os momentos. Nesse caso, quem foi fotografar foi o João. Como podíamos levar até duas pessoas, colocamos a mulher dele como assistente e foram os dois para o carnaval. Antes da viagem, rolou uma conversa sobre aquelas pessoas que ficam em baixo do trio elétrico, pedimos para o João tentar fazer umas imagens disso. 0 João voltou com as fotos e, a partir daí, iniciamos uma discussão. Nós tínhamos um trabalho para fazer e aproveitamos essa situação para fazer a nossa história.

O Longa Exposição também veio disso. Era a época do lançamento das câmeras 5D e nós fazíamos muitos retratos para editoriais. Um dia recebemos a encomenda de uma revista para fazer um retrato da Elza Soares. Fomos lá, fizemos os retratos e, ao final da sessão, pedimos para ela ficar em um fundo branco e fizemos o vídeo. A mesma coisa com a Pitty, com o Hector [Babenco]. Às vezes pagavam pouco, mas, se era uma celebridade que pudesse dialogar com o trabalho, topávamos só por conta do projeto. Isso era muito bacana da Cia, o grupo não se prendia ao mercado, mas utilizava os recursos, aproveitava o acesso [...]. Seja qual fosse a pauta, a pessoa sempre voltava com algum experimento. Às vezes, não dava em nada, mas às vezes dava em alguma coisa.

o País Interior, aquele trabalho a partir do filme do Glauber Rocha, surgiu a partir de uma provocação. Era um ano em que eu estava com pouco trabalho e começamos a pensar em como seria colorir os frames de um filme antigo. Eu peguei um vídeo, fiz uns testes e todo mundo pirou, então começamos a pensar a partir disso. Às vezes, o conceito vinha antes, às vezes, a experimentação vinha primeiro e se trabalhava depois no conceito. O processo mudava um pouco, mas era sempre a partir de provocações, seja de texto ou de ulguma forma estética. Às vezes, convidávamos alguém de fora do coletivo para ajudar a pensar e a construir o trabalho - críticos, pessoas que trabalhavam junto com a gente... Era um coletivo que se ramificava, não ficava contido só nele mesmo.

CS:

Tem algum trabalho mais representativo desse modo de funcionamento? 
CL:

Não sei, não consigo pensar em um trabalho único, são etapas, sabe? Eu sempre falo em aula que a pesquisa de um artista é uma coisa só, você vai vendo o desenvolvimento dela em vários trabalhos, uma coisa leva a outra... No caso da Cia, eu vejo muito isso. Havia uma coisa dos trabalhos iniciais que foi se desdobrando em formas estéticas diferentes. Olhando de fora, dá para perceber que havia questões que foram muito trabalhadas - o que é a imagem fotográfica, o que é a imagem parada, o que é a imagem em movimento, o que é a luz, o que é a sombra, o que é o escuro. Há trabalhos que eu gosto mais, trabalhos com os quais eu me envolvi mais efetivamente. Eu adoro o País Interior, adoro o Retiro, porque são trabalhos com os quais eu tive bastante contato, fiquei mais tempo envolvida. [...]

CS:

O modo de trabalhar da Cia mudou muito ao longo do tempo?

CL:

Acho que sim, talvez até por isso que tenha acabado... Mas é difícil fazer essa autoavaliação. Eu penso mais em como foi minha trajetória: comecei em formação, depois fui crescendo, passei a ter uma posição mais forte, uma opinião de igual para igual. 0 modo de trabalhar talvez não tenha mudado tanto porque havia várias vertentes de trabalho. Nós éramos muito movidos por experimentação e provocação. Não sei dizer se mudou muito, mas uma coisa é fato: eu saí de lá e não consegui encontrar um esquema de trabalho igual ao que tínhamos na Cia. Havia uma sinergia muito boa, um entendia o que o outro estava falando. Não eram só flores, pelo contrário, brigávamos bastante [risos], mas as coisas eram lisas, sabe? Era um ambiente saudável de se trabalhar e quem não conseguia entrar nesse esquema saía rápido. Tem histórias de sócios que entraram, ficaram pouco, saíram e deram prejuízo. Não era qualquer um que ficava, quem ficou estava em sinergia.

Quem pode falar melhor se a forma de trabalho mudou são o Pio e o Rafa, que estavam desde o começo. Eu comecei moleca, às vezes você não tem muita consciência do que está acontecendo. Os meninos começaram ali já entendo do funcionamento financeiro, eles sabiam de tudo. Eu não sabia, essas coisas não passavam por mim. Começaram a passaram no último ano, que foi o ano em que não trabalhamos e o dinheiro acabou. Trabalhamos pouco, as economias foram indo embora e não deu para manter o esquema que tínhamos por lá. Eu não tive noção da importância da Cia até o coletivo acabar. Teve esse impacto, as pessoas ficaram muito impressionadas. Sei que tivemos um papel bacana dentro da fotografia latino-americana por iniciar esse processo de coletivo que radicaliza a assinatura. Não é um modelo que todos os coletivos têm, mas 
funcionava para nós, existia a necessidade de criar uma coisa única, de juntar a colaboração de cada um, colocar no mesmo saco e ver o resultado.

Participamos de vários encontros de coletivos de fotografia e tivemos contato com vários modelos, mas poucos com essa coisa de assinar em grupo. 0 primeiro encontro foi aqui em São Paulo, e foi engraçado porque éramos o único que assinava realmente como coletivo. Colocamos uma pulga atrás da orelha de todos os grupos que vieram. E o pessoal ficou muito comovido quando falamos que a Cia tinha acabado. Mas talvez seja por isso que tenha acabado, era tudo muito em conjunto. Com o tempo, você vai criando afinidades, vai perdendo a paciência de fazer de tudo um pouco. E, no nosso caso, era tudo compartilhado, nós tínhamos pró-labore, era tudo dividido, até nos trabalhos de publicidade. Se alguém trabalhasse mais em um trabalho, o cachê não seria maior. Eu não tinha filhos, então meu custo de vida era mais baixo e eu ganhava menos. O Rafa e o Pio tinham filhos, tinham um custo de vida um pouco maior, então ganhavam mais. As divisões eram nesse sentido. Mas, ao mesmo tempo, é uma posição que acaba gerando acomodação, ela não te incentiva a correr atrás das coisas, o pró-labore está garantido. Talvez aí tenha ocorrido um erro, essa ideia de tentar levar para o financeiro o formato que nós tínhamos no lado conceitual. Chegou em um momento em que a coisa não se sustentou.

\section{CS:}

Tu falaste nessa junção de pessoas diferentes que fazem um trabalho que acaba assumindo uma identidade coletiva. Qual era o papel dessas individualidades dentro do coletivo? Eu também gostaria que tu comentasses um pouco sobre a criação dessa identidade coletiva que, às vezes, pode se tornar mais forte do que uma assinatura individual. Muitas vezes, só pelas imagens já dava para saber que determinado trabalho era da Cia.

\section{CL:}

Todos tinham personalidades muito fortes e bem diferentes entre si. Havia briga o tempo inteiro. Você ia conversando, conversando, e cada um abria mão de uma coisa. Cada um tinha uma opinião muito forte sobre o que estava fazendo. E por isso acho que dava certo, porque a coisa era tão discutida internamente que, quando ela tomava a rua, já estava completamente resolvida. Quebrávamos muito a cabeça quando estávamos desenvolvendo algum trabalho. Quando vinha uma terceira pessoa, já tínhamos passado pela fase de concordar ou não com aquilo, já se tinha chegado a um consenso sobre o que era o trabalho.

CS:

Esse consenso era discutido a cada vez? 
CL:

A cada vez, cada trabalho era uma coisa diferente. Nós fazíamos, imprimíamos, colocávamos na mesa e discutíamos. Eram perfis bem diferentes, o Pio nos últimos anos se voltou muito para a pesquisa, entrou para a filosofia, fazia leituras, escrevia. O Rafa é um cara mais de ação, que dizia vamos lá, vamos fazer isso, e o João é o tipo autista-gênio, que ficava calado e de repente vinha com uma coisa genial e espantava todo mundo. Aí juntou tudo isso, e eu ficava ali, intermediando. Mas também pode ser enlouquecedor, precisa ser muito paciente, esperar captar o momento de cada um... Às vezes, um trabalho precisava de uma mão mais pesada do Pio, às vezes, era um esquema para o Rafa, que simplifica as coisas difíceis. E o João conseguia soluções criativas muito rápido. Quando ele queria, porque às vezes ele simplesmente ficava quieto. Mas era preciso respeitar o tempo do outro.

O que dava uma uniformizada na história, além da edição e da pós-produção, era o fato de que o trabalho era muito discutido internamente [...]. E, da mesma forma que os meninos tinham uma personalidade muito forte, eles também tinham um desapego muito grande com as imagens. Não é todo fotógrafo que tem. Eles jogavam na roda e víamos as fotos que funcionavam. Nós juntávamos tudo em uma pasta e íamos editando, enxugando, não precisava saber de quem era. Claro que, nas minhas organizações de arquivo, eu tinha um jeito de colocar a informação de quem fotografou. Isso ajudou bastante no fim [risos]. Quando eu estava tratando uma foto, eu precisava saber de quem era para poder tirar alguma dúvida de pauta.

\section{CS:}

Interessante esse fato de que, para fins práticos, era preciso identificar quem fazia cada foto. Há um discurso meio rápido que afirma que nos coletivos as identidades se anulam, que não existe autoria...

CL:

Não, pelo contrário, as individualidades estavam presentes lá dentro o tempo inteiro, não se anulavam de jeito nenhum. Era por conta delas que existia uma unidade. As coisas eram tão discutidas, tão pensadas, que se chegava a um comum acordo.

CS:

Dez anos me parece um tempo bastante longo para esse tipo de processo, é bem trabalhoso, desgastante... 


\section{CL:}

Ah, é... O Rafa e o Pio já se conheciam antes de formar a Cia, eles têm esse percurso mais longo. $E$ tudo realmente veio da necessidade que eles tiveram de tentar pensar outra forma de trabalhar. No final, acabou não dando tão certo, mas acho que o tempo que durou deve ser comemorado, rendeu frutos bacanas.

Todas as entrevistas foram realizadas em São Paulo em dezembro de 2015 e estão organizadas pela ordem em que ocorreram. Como os textos precisaram ser reduzidos em alguns trechos, foram priorizadas informações sobre a constituição do coletivo, formas de atuação e trabalhos mais representativos. 0 material foi coletado por ocasião da pesquisa de doutorado de Camila Monteiro Schenkel, realizada no PPGAV-UFRGS com bolsa CAPES, que resultou na tese Manter os olhos abertos diante do abismo: a produção compartilhada de imagens em coletivos de arte contemporânea, defendida em outubro de 2016.

\section{Carolina Lopes}

Graduada em Arte e Mídia pela Universidade Federal de Campina Grande e pós-graduada em Fotografia pelo Senac-SP. Trabalhou com a digitalização, a edição e o tratamento de imagens do arquivo da fotógrafa Nair Benedicto e atuou como professora de cursos voltados para a fotografia digital.

\section{João Kehl}

Formado em Fotografia pelo Centro Universitário Senac -SP (2005) e iniciou seu trabalho em fotografia fazendo assistência para fotógrafos. Atualmente trabalha com Rafael Jacinto como fotografia e direção de cena para os mercados publicitário e editorial

\section{Pio Figueiroa}

Iniciou sua carreira em fotojornalismo em Recife, no Jornal do Comércio, em 1995. Dois anos depois, mudouse para São Paulo, onde trabalhou para a Editora Abril, para a Editora 3 e para o jornal Valor Econômico. Atualmente, trabalha como fotógrafo e diretor de cena. É editor da revista latino-americana de fotografia Sueño de la Razón e do blog Icônica.

\section{Rafael Jacinto}

Graduado em Comunicação Social pela Fundação Armando Álvares Penteado (1998) com ênfase em rádio e televisão. Ainda durante a faculdade, começou a trabalhar como fotógrafo freelancer para revistas de skate e de surf. Foi repórter fotográfico do jornal Notícias Populares e fez parte da equipe-piloto do Valor Econômico.

\section{Camila Monteiro Schenkel}

Doutora em Artes Visuais pelo PPGAV/UFRGS na área de concentração História, Teoria e Crítica da Arte, onde realiza pesquisa de pós-doutorado com bolsa CAPES no ano de 2017. Foi professora temporária do curso de História da Arte do Instituto de Artes da UFRGS e coordenou o Programa Educativo da Fundação Iberê Camargo de 2012 a 2017.

(*) Texto enviado em setembro de 2017 